\title{
Analysis Of The Calculation Of The Inheritance In The Family
}

\author{
Sriono ${ }^{* 1}$, Sri Dewi ${ }^{1}$, Hendra Sony Rambe ${ }^{1}$ \\ Universitas Labuhanbatu \\ *Coresponding Author: \\ Email: sriono@ulb.ac.id
}

\begin{abstract}
This research discusses about the calculation of the division of the inheritance against his polygamous wives. the method used in this research is using a normative juridical approach, namely by using the approach to laws and regulations applicable in Indonesia as well as the norms that live in society, data obtained from secondary data, namely the rules and regulations and the material of literature. Marriage polygamy is a marriage which one of it where men have or marry more than one womenor wife. Inheritance is an integral part of a marriage where the legal heirs are divided into two principles of marriage including monogamy and polygamous marriage. As for the calculation part of the legacy of the wives of a polygamous marriage calculated from the wealth obtained from each mating that they do. The division of property in a law of inheritance i.e., by observing the position of each wife. While the right part of the wife is shared jointly by the part of the wife such as $1 / 4$ if there are no children and $1 / 8$ if there are children.
\end{abstract}

Keywords :Marriage, Polygamy, calculation, part of the inheritance

\section{INTRODUCTION}

A marriage recognized invalid according to the laws of the state of Indonesia, namely marriage in the initiate according to the religion and belief of the bride and groom and recorded in the office registration of marriage[1]. The principle in the law of marriage adopted by Law No. 1 Year 1974 on Marriage (LAW No. 1 of 1974) that is monogamous (a man may only marry a female and vice versa), although such principle is not applicable absolute but rather the leeway that a man may marry more than one to meet the requirements that have been determined. Things such as set forth in Article 3 paragraph (2) that to a man who would marry more than one wife is allowed with or desired by the parties concerned.

Marriage performed for the second and subsequent have to get permission from the court. Permission obtained from the court based certain reasons. The provisions related to permit mating to the second and subsequent set forth in Article 4 and 5 of the LAW No. 1 Year 1974. While related to the ordinance shall be further regulated in government Regulation Number 9 Year 1975 about the regulation implementing the Law of Marriage. In real life often happens marriage for the second and subsequent or so-called has more than one wife but the marriage is not conducted based on the provisions stipulated in the Marriage ACT in particular with regard to registration of marriage. Marriage is not done under the provisions of the Marriage ACT occurred because the men assume that the permission to marry again may not be obtained.

So also in the Compilation of Islamic law (WHEN) arranged a valid marriage is when done according to islamic law compatible with Article 2 of the law of Marriage and was recorded by the officer of the clerk of wedlock. So, in addition to the need to fulfill the conditions and pillars of marriage as stipulated in the law of islam, but also needs to be recorded in the Office of Religion (KUA) by the official scribe of wedlock. Recording of wedlock this has the meaning of a guarantee of legal certainty about the status of marriage with all its legal consequences posed. Then the footage is a necessity, and the requirements of the primer that must be met for each of the spouses, until the rights of each will be guaranteed by law. This is different with the meaning of marriage sirri, which in the legislation has the purpose of hidden, kept secret, and not announced to the outside world. Whereas in the meaning of verification in Indonesia,marriage sirri is a marriage performed in islamic law and is not known to a lot of people, just not sent to the Office matters of Religion. So, the difference between nikah sirri and not the act of marriage as proof of marriage[2].The functions and benefits of 
entering marriage is for proof of authentic if nothing happens in a marriage for instance determine the status of children born in the marriage between the couple and if that happens the divorce act marriage which is being used as evidence and a tool to solve it[3].

In life sometimes there is a death, when the death of someone that happened then will arise the rule of the law. Such as the rule of law such that the law of inheritance. Against wife in a polygamous marriage the good wife the first, second, third, or fourth can arise problems in case of inheritance, basically the same - the same is entitled to acquire the inheritance. Things like where on the layout in the compilation of islamic law in article 190 of them to the heir hitched more than one, then each wife is entitled to get the upper part of the marital property from the home with the husband, whereas the rest part of the heir is to be the right heir. Yet, with a record of a marriage has done in legal good according to the law of the country and religion. the marriage of the second, third and fourth do not do according to the rules of law which resulted in marriage which is not valid[4].

The problems will be in against polygamous marriage that is mengenaipembagian heirs. According to Islamic law, in a marriage happens then in the case of property in a marriage will be the joint property (gono gini). Joint property (gono gini) dariperkawinan polygamy because of the joint property, it can happen permasalahanketika occur the seizure of the treasure due to no distinct separation between the hartabersama from each marriage.

According to mawardi muzamil that the islamic inheritance law is the provisions governing the calculation and division as well as the removal of the inherited property in a fair and evenly distributed to heirs and / or the person / entity to another who is entitled to receive as a result of the death of a person[5]. Inheritance law is the provisions about the transition of wealth from within who have died for the heir. The inheritance law applicable in Indonesia, including the three types of laws of inheritance, namely inheritance law, islamic, civil and customary, it is related because before the issuance of Law Number 12 Year 2006 About Citizenship using a system of classification in accordance with Article 163 Indische Staatsregeling. With regard to the entry into force of the law of inheritance is based on the groups each including the islamic inheritance law is applicable for people of indonesia are muslims[6].Inheritance law regulates the rights belonging to a person on property that is owned after the person died, in other words arrange the transfer of assets left by a person who has died and the consequences for the heirs. Basically, the rights and obligations in the field of property laws bisadiwariskan. Sometimes belonging to the dead are not divided during adajanda and children who are not yet adults[7].

\section{REVIEW OF LITERATURE}

A man or husband to be married must meet the requirements as stipulated in LAW No. 11974 , and PP No. 9 1975. Article 3 of the LAW No. 11974 mentions that the Court can give permission to a husband to marry more than one if desired by the parties concerned. Likewise, to obtain a permit mating of such must apply to the court. As for the reason that can be asked to get permission from the court about a permit mating of more than one stipulated in Article 4 and 5 of the LAW No. 1 of the Year 1975 as follows:

Article 4 "the Court only gives permission to the seorangsuami to be married more than a if:

a. wife can not perform its obligations as the wife of;

b. wife got a defective body or a disease that cannot be cured;

c. wife can not give birth to offspring."

Article 5, namely that to be able to apply to the Court, as referred to in Article 4 paragraph (1) of this Act, must be met the following requirements:

a. the consent of the wife/wives; children;

b. the certainty that the husband is able to guarantee the necessities of life wives and their

c. the guarantee that the husband will be valid and fair to the wives and their children

Article 42 of PP No. 91975 mentions that:

1. In conducting the examination, the Court shall summon and hear the wife is concerned.

2. Examination of the the Court to was done by the Judge no later than 30 (thirty) days after receipt, letter of request and their annexes.

Article 43 PP No 9 Tahun 1975 "If the Court argue that the sufficient reason for the applicant to married more than one, then the Court gives its verdict in the form of permission to marry more 
than one". Whereas if not in accordance with the provisions of the registrar reserves the right to refuse.to record the marriage is conducted (Article 44 of regulation No. 9 1975).While the settings related to Polygamy on the Compilation of Islamic Law stipulated in Article 55 to 59.

\section{Basic inheritance law}

According to the opinion of Rudolf Von Ihering (1818-1892), which states that the law is the whole of norms that force that prevails in a Country, and Hans Kelsen stated the law consists of the norms of how people should behave. This opinion is supported by legal experts from Indonesia, Wiryono Projodikoro (1983) who say the law is a series of regulations on the behavior of people as members of a society [8].

The law of inheritance prevailing in Indonesia at this time refers to the 3 rules of inheritance, namely:

1. Islamic inheritance applicable for citizens of indonesia is muslim;

2. Heirs of the civil code applicable for citizens of Chinese descent and that is equivalent to it;

3. Traditional inheritance applies to community customs (valid for indonesian citizens outside the religion of islam).

Settings against polygamy in terms of inheritance based on the three rules of inheritance law which is set out in clear and unequivocal as well as dikoodifikasikan in the form of rules exist in the islamic inheritance law. The rules relating to the inheritance of their wives, polygamy is set more in the Compilation of Islamic Law.

The teachings of Islam about the arrangement of the law gives an overview, how the real Islam has to organize the life of this man with the laws wherewith set. The theory or doctrine about the arrangement of the law according to the Islamic perspective comes from God as the creator of the shari'a in the form of revelation, namely the Qur'an. He can be said to constitute the normative law is universal and applies to all human beings without distinguishing the position of race, politics and social culture. The universality of the law of the qur'an that require explanation in the form of implementation of the law that are practical. This is done the Prophet through everyday life, in the form of normative law are applicable, i.e. As-Sunnah. Whenever there is the absence or obscurity of the law intended by Allah and His prophet in Al-Quran and As-Sunnah, then the formation of the ruling handed over to the human, through the method of ijtihad. The doctrine of the arrangement of this law states that for every believer to run his kaffah[9].

The law of inheritance islam is the law which regulates everything relating to the subject of the rights and obligations of the treasures of one's wealth after he died to heirs. And the law of inheritance is also called the law of faraidh. The source of islamic law originated from the al-quraan, especially the letter An - Nisa verse 7,8,9,10,11,12,13,176. Surat Al - anfal : 75 and Al - hadith contains the sunnah of rasullullah which is then developed in detail by legal experts of islamic jurisprudence via ijtihad, in accordance with space and time, situation and conditions.

\section{METHODS}

The research method used in this research is using the method of normative juridical which refer to the provisions of the legislation are positive in indonesia in between laws and regulations on the rights of the mewaris in the division of islamic law by way of knowing the ordinance of the rules of the law of inheritance islam as well as making it as guidelines in resolving the issues of inheritance in terms of division of rights mewaris for the wives of polygamy in indonesia.

As for the regulations used in this study as a form of solving the problems that occur are:

1. The law of the Republic of Indonesia Number 1 Year 1974 about Marriage;

2. Regulation of the government of the Republic of Indonesia Number 9 Year 1975 about the Implementation of Law Number 1 Year 1974 About Marriage.

3. The Instructions Of The President Of The Republic Of Indonesia Number 1 Year 1991 About Compilation Of Islamic Law.

In addition to the above literature were used, namely the Koran and the Hadiths. In this study, refers to the direction of the secondary data research. Thus there are main activities to be performed in carrying out this research, namely the literature study (library research), which was obtained through literature, by way of review, study, and manage the literature of the legislation by way of researching through the the article-artikelyang related issues will be examined. 


\section{RESULT AND DISCUSSION}

Law Number 1 year 1974 about Marriage, arrange that a husband is allowed to marry to more than one wife. A husband who would marry more than one woman have to get permission from the first wife/wives or with the written consent of the first wife. Settings related to the marriage of the second and subsequent set out in articles 3,4,5 of the Law Number 1 Year 1974 and its implementation regulation No. 9years 1975. Islam regulates marriage more than one as found in alQuraan surah an - Nisa verse 3 has the meaning of a man allowed to marry more than one wife and a maximum of 4 wives with the provisions of the applicable fair.

The law of inheritance arise from the presence of an event. The events in question, namely the death of a person. The law of inheritance spoke of wealth and heirs. With the death of a person then the resulting inheritance law, based on Article 35 of LAW No. 1 Year of 1975 that the property in a marriage is distinguished into two parts, namely a treasure of innate and treasure together. Against the wealth in a marriage if the marriage broke up (the rupture of the marriage because of death, divorce and court decisions) applies the provisions of the respective law (Article 37 of LAW No. 1 1974). The provisions relating to joint property if one partner dies the world is not regulated expressly in the LAW No. 11974 likewise in the Book of Law Civil Law (the civil Code). Settings related provisions of the joint property if one partner dies the world is set clearly and firmly in Article 96 of the Compilation of Islamic Law (KHI) that occurs when the divorce is dead then the joint property becomes the property or rights of couples who live the longest. As for the terms of distribution of the assets if the death of one of the spouses dies the world is formulated as follows:

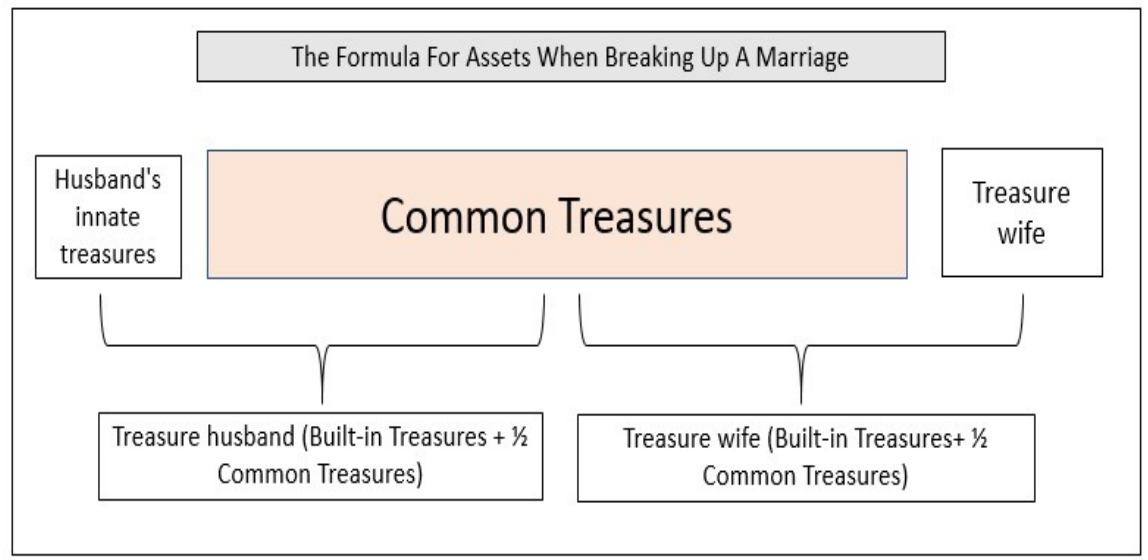

Fig 1. The formula of distribution of the assets in a marriage

The provisions of inheritance laws between the law of islamic inheritance, inheritance the civil code and the inheritance customs have difference. As for the difference from the third law of inheritance can be seen in the following table:

Table 1. The difference in the islamic inheritance law, civil, and customary.

\begin{tabular}{|c|c|c|c|c|}
\hline NO & Description & $\begin{array}{c}\text { Islamic } \\
\text { Inheritance }\end{array}$ & Civil Inheritance & $\begin{array}{l}\text { Traditional } \\
\text { Inheritance }\end{array}$ \\
\hline 1 & The legal basis & $\begin{array}{l}\text { Alqur'an, Hadith } \\
\text { and Ijtihad }\end{array}$ & KUHP Civil & Customary Law \\
\hline 2 & The heirs & $\begin{array}{l}\text { Divided into } 3 \\
\text { parts, namely } \\
\text { Dzawil furud, } \\
\text { Ashobah, and } \\
\text { dzawil arhan }\end{array}$ & $\begin{array}{l}\text { There are } 4 \\
\text { groups that are } \\
\text { close to each } \\
\text { other }\end{array}$ & $\begin{array}{l}\text { Based on the } \\
\text { type of kinship } \\
\text { that embraced }\end{array}$ \\
\hline 3 & $\begin{array}{l}\text { The magnitude of the part of the } \\
\text { right heirs of the }\end{array}$ & $\begin{array}{l}\text { Determined in } \\
\text { accordance with } \\
\text { the provisions of } \\
\text { the heirs of such } \\
\text { as } 1 / 2.1 / 3,1 / 4,1 / 6 \text {, }\end{array}$ & $\begin{array}{l}\text { The amount } \\
\text { adjusted by the } \\
\text { number of heirs } \\
\text { (divided } \\
\text { according to head }\end{array}$ & $\begin{array}{l}\text { Determined } \\
\text { based on the } \\
\text { type of kinship } \\
\text { such as java } \\
\text { with the term }\end{array}$ \\
\hline
\end{tabular}




\begin{tabular}{|l|l|l|l|l|}
\hline & $\begin{array}{l}1 / 8,2 / 3 \text { and } \\
\text { ashobah (the rest } \\
\text { of the) }\end{array}$ & $\begin{array}{l}\text { segendong } \\
\text { sepikul (2:1) }\end{array}$ \\
\hline
\end{tabular}

In the law of inheritance islam, the islamic inheritance law is the law that regulates everything with regard to the transfer of rights and obligations on the basis of the wealth of a person after he died in instructed his heir, the inheritance law of islam is called as the law of faraidh. The study of people who inherit and do not inherit the content of the received each of the heirs and how to the division. The law governing the transfer of ownership rights ommission (tirkah) the testator, determine who is entitled to be the heirs and how its each part (KHI Article 171 (a)).

The Islamic inheritance law is a science and law that should be studied as the hadeeth of Abdullah Ibn Mas'ud that the Messenger of allah said yangartinya Study the Qur'an and teach it to others, as well as learn faraid and teach it to others. Indeed, I'm a gonna die, and this knowledge was going to disappear until the fitna will appear. Even happen to be two people that will be disputed in the case of division (a right that should he accept), but they don't have people that can resolve such disputes, (HR.Narrated by al-daaraqutni)[10].

The thing that was obtained in determining the treasures tirkah the switch kepadaahli heir in a polygamous marriage with how to separate the joint property of each of the polygamous marriage. When where the absence of in do bonding agreement between the wife of the wife in polygamy and in terms of the separation of the joint property before the marriage carried on. And when where there is an agreement of separation of joint property then it will be easier in determining the treasures which the rights of the testator (the husband) and the other half becomes the right of each (the wife). For the couple husband and wife who do not covenant the separation of joint property before marriage then the treasure that obtained from the marriage split in two parts, Half being right of the husband (the heir) and the other half becomes part of the wife, better than the wife of the first, second, third and fourth. Then half part of the right of the husband (the heir) from each marriage first reduced with the financing bodies, the payment of the debt or the granting of probate. In the LAW No. 1 year 1991 about compilation of islamic law on article $176-182$, basically there is no difference in the magnitude of the portion or portions for heirs both in monogamy and polygamy however, the difference lies only in the nominal amount of the inheritance that was obtained from the heirs because of the difference in the magnitude of joint property between each polygamous marriage that is influenced by the state of the economy at the time of marriage, and justice in the distribution of the testator (the husband) to the respective wife or to the child. And also on view through the duration or lamaya a bond of marriage.

In a polygamous marriage better in the view of civil law, customary law or in the view of islamic law. Got a lot of difficulty in which to determine the joint property. Because in a polygamous marriage that often occur in indonesia, especially the city of rantau prapat of north sumatera province is very rare to register on the institution of marriage registrar. Because the recording of the marriage in the polygamous marriage of course have to get permission or the consent of the first wife, second wife and so on through the courts. Because in the review directly rarely happens to a woman or the first wife give permission so that the husband can perform a polygamous marriage.

Because marriage polygamy is not recorded, and will cause barriers and conflict later in the day both in the exercise of the right division of the heirs. Because many cases it often happens that a husband never tell a wife that he had done a polygamous marriage. And polygamous marriage is not strong her marital status only to the extent of marriage in the hands. In the sense of marriage which is based on the polygamous relationship will be hard to get her rights to be a part of the heirs.

The factors that be the cause of the problems in the division of the estate of a polygamous marriage that is :

1. The implementation of the polygamous marriage is done secretly and the secret and status of the letter under the hand.

2. In laksanakannya marriage without the permission of the first wife or wives before.

3 . In doing polygamous marriage but not recorded or reported the existence of the marriage.

4. The absence of clarity about the treasures of the relics of the regionand not registered.

5. The absence in doing the separation of joint property among the treasures of the default of the party of the first wife.

6. Every marriage is not in doing a covenant marriage is. 
It can be seen and felt that marriage which is done in polygamy can pose a barriers are very large including in the division of inheritance rights if the husband died.

How to determine the inheritance yangberalih to the heirs in marriage polygamy is a dahulumemisahkan the joint property of each marriage polygamy (if not adaperjanjian to the separation of joint property before marriage it is implemented). Bilaada agreement separation of joint property then it becomes easier dalammenentukan treasure of which being the right of the husband (the testator) and of the treasure which became the rights of each wife. For the couple husband and wife who do not melakukanperjanjian separation of joint property before marriage, then joint property darimasing of marriage is divided into two parts, half being right of the husband(the heir) and the other half to be the right wife (the first wife or second or third ataukeempat). Then half part of the right of the husband (the heir) of each marriage first be reduced by the cost of maintenance of bodies,payment of debts, the granting of probate. The results are then distributed to the expert warisyang entitled to. Heir is a person who has a blood relationship atauhubungan marriage with the testator as brothers and sisters of the testator, his children, wife,parents of the testator. Large part to each of the heirs have been determined by al qur'an-Surah An-Nisaa' verse 11, 12, 176; Al-Hadith; and Presidential decree No.1 1991[11].

Experts warisdalam polygamous marriage is to divide the treasure bersamadari each marriage into two parts (when no perjanjianperkawinan that has been previously created to perform the separation hartabersama) then half of the menjadihak wife (the first wife or the second atauketiga or fourth) and half part to be the right of the husband (the testator). When adaperjanjian marriage between the husband (the heir) with each istrinyauntuk perform the separation of the joint property then it becomes easier dalammenentukan the treasures which belong to the wife and the treasures which menjadimilik husband (the heir)[11].

The acquisition and inheritance rights of the wife of the second, third, and fourth, in Al-qur'an surat An-Nisa verse 12 uses the word "LAHUNNA" which has the meaning of the wife, where the author tries to interpret about the acquisition and the rights of inheritance of the wife here is a husband who has more wives than one if died and at the time died leaving more than one wife then the wife to get the acquisition and the estate of $1 / 4$ (a quarter) if the husband leaves no children. The wife is earning and the estate of $1 / 8$ (one-eighth) if the husband left the child.The how with how the division of the meaning of the 1/4 (a quarter), and 1/8 (one-eighth), can be defined that the $1 / 4$ or the $1 / 8$ is calculated based on the number of wives that exist when the husband died. If the husband died, leaving 2 (two) wives and have children then the acquisition and the right heirs of the second wife get $1 / 8$ a section in for with 2 (two) wives each wife get the $1 / 16$ part. If the husband died, leaving 2 (two) wives and not have children then the acquisition and the right heirs of the second wife get a $1 / 4$ section in for with 2 (two) wives each wife get $1 / 8$ part[12].

As for the system of distribution of the assets to the wife polygamy (lahuna) described as follows:

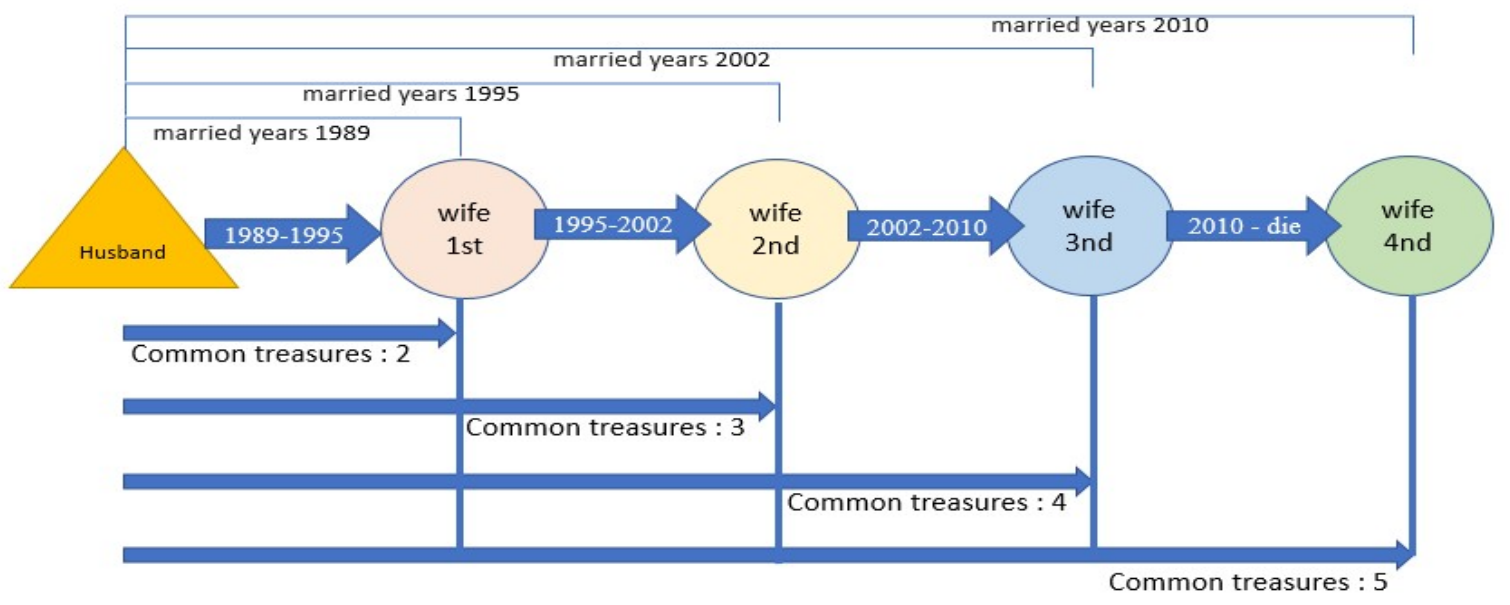

Fig 2. The scheme of distribution of the assets to the wife polygamy (Lahuna) 


\section{CONCLUSION}

The division of inheritance based on the inheritance law that applies in Indonesia should pay attention to the group of heirs as if they are muslims then using the law of islamic inheritance, the descendants of chinese and equivalent using the law of inheritance the civil code, and for indigenous people (outside the religion of islam) to use the traditional inheritance law. Marriage on the principle adheres to the system of monogamy but are not mutla but the leeway that is allowed to marry/married more than one wife had to meet all the requirements specified in the regulations. To the wives of the polygamous marriage if the husband dies then the rights of the wife to property is taken into account based on a marriage that they do, while the setting of the magnitude part of the right heirs of the wife according to the islamic inheritance law as stipulated in the al - qur'an surat an - nisa verse 12 (QS. 4, 12 ) and KHI, namely the acquisition of a wife set in article 180 . The rights of the wife is to get $1 / 4$ or $1 / 8$ and divided together.

\section{REFERENCE}

[1] Undang-Undang Republik Indonesia Nomor 1 Tahun 1974 tentang Perkawinan. .

[2] Z. Lutfiyah, "Status Pernikahan Siri Dalam Aturan Perundang-Undangan Di Indonesia." [Online]. Available: https://adoc.tips/status-pernikahan-siri-dalam-aturan-perundangundangan-di-in.html.

[3] M. Y. Harahap, Pembahasan Hukum Perkawinan. Jakarta: CH.Zahir Trading Co, 1975.

[4] Instruksi Presiden Republik Indonesia Nomor 1 Tahun 1991 tentang Penyebarluasan

\section{Kompilasi Hukum Islam.}

[5] M. Muzamil, Hukum waris tanpa wasiat menurut Undang-Undang Hukum Perdata. Semarang: Unissula Press, 2006.

[6] S. Sriono, "Sistem Pewarisan Pada Warga Negara Indonesia Keturunan Tionghoa (Cina) Muslim," J. Ilm. Advokasi, vol. 5, no. 2, pp. 110-122, 2017.

[7] S. S. Muhammad Yusuf Siregar, Risdalina Risdalina, "The Position of Women's Heritage Rights in the Context of Islamic Heritage in Indigenous Mandailing in Sipirok District,

Tapanuli Selatan Regency,” Budapest Int. Res. Critics Inst. Humanit. Soc. Sci., vol. 3, no. 1, pp. 531-539, 2020.

[8] T. P. D. A. H. Barkatullah, Filsafat, Teori \& Ilmu Hukum Pemikiran Menuju Masyarakat Berkeadilan Dan Bermatabat. Jakarta: PT. RajaGrafindo Persada, 2014.

[9] H. M. R. A. A. Rahmat Rosyadi, Formalisasi Syariat Islam Dalam Perspektif Tata Hukum Indonesia, 1st ed. Bogor: Ghalia Indonesia, 2009.

[10] M. A. Ash-Shabuni, Pembagian Waris Menurut Islam. Jakarta: Gema Insani, 1995.

[11] V. A. Septianingsih and N. Maghfiroh, "Pembagian Harta Warisan Dalam Perkawinan Poligami Perspektif Hukum Islam," Varia Justicia, vol. 11, no. 1, pp. 49-64, 2015.

[12] D. Sukardi, "Perolehan Dan Hak Waris Dari Istri Kedua, Ketiga Dan Keempat Dalam Hukum Kewarisan Islam Di Indonesia (Sebuah Pemahaman Dengan Ilmu Hukum, Filsafat Hukum Dan Paradigmatik)," J. Huk. dan Pembang., vol. 44, no. 3, pp. 435-459, 2014. 